THIS ARTICLE HAS BEEN PUBLISHED IN A SLIGHTLY DIFFERENT VERSION: LEGAULT, MARIE-JOSÉE (2010) "ARE LESS EDUCATED WOMEN IN THE BLIND SPOT OF PAY EQUITY?", JOURNAL OF WORKPLACE RIGHTS, VOL. 14, NO 2, P. 141-268

\title{
ARE LESS EDUCATED WOMEN IN THE BLIND SPOT OF PAY EQUITY?
}

Marie-Josée Legault, École des sciences de l'administration (ÉSA-Téluq) and CRIMT

mjlegaul@teluq.ca 


\section{ABSTRACT}

In this article I will show two things: first, that the labour market is still very divided with respect to gender and, second, that the material impact of this division differs sharply by level of education. Among occupations that require the least education, women pay a very high price for this gender based division of employment. In contrast to occupations where more education is needed, those requiring the least education show a huge difference in wages according to whether they are predominantly male or predominantly female. This difference is a widespread phenomenon that favours so-called male occupations. The corresponding pay gap, in favour of men, in occupations requiring a high school diploma (Secondary V in Quebec) or less, is shrinking only slightly, whereas the gaps between men and women in occupations requiring more education are clearly closing. The article then demonstrates that three often mentioned options for action, at present, offer little hope to counter that particular phenomenon: Quebec's Pay equity act application, collective bargaining and internal promotion. Yet, this problem still affects approximately 500,000 women, after 25 years of equal access programs and close to 15 years of implementation of the Pay Equity Act. Employment equity programs are the most promising initiatives, provided that they find their way into the affected employment sectors.

\section{Keywords}

Labour market segregation; gender bias; gendered wage gaps; unskilled labour force; employment equity; pay equity

\section{INTRODUCTION}

While women have made a number of gains in terms of labour force participation, the division of labour is still largely gender based. Indeed, there is a gendered concentration of workers in certain occupations and certain jobs, even though other occupations have a more mixed workforce. After 25 years of employment equity policy in Quebec, some jobs still have such a high concentration of women or men that they can be called predominantly female or predominantly male.

To determine whether an occupation is predominantly female or male, the Institut de la statistique du Québec (ISQ) uses a diversity index that can be defined as the difference between the proportion of men or women in the overall labour force and their proportion in a specific occupation. 
In 2006, for instance, the proportion of women in the labour force was $47 \%$, while that of men was $53 \%$. An occupation is considered female if the proportion of women in that occupation is equal to or greater than the $47 \%$ in the labour force, and predominantly female if the proportion of women is equal to or greater than $73.5 \%$. Conversely, if women account for less than $47 \%$, the occupation is termed male, down to a female proportion of $23 \%$, and predominantly male if the proportion of women is less than $23 \%$.

Of the 520 occupations listed in Canada's National Occupational Classification (NOC), in 2006, 347 were deemed male or predominantly male and 174 female or predominantly female (Table 1). There were therefore virtually twice as many predominantly male occupations as predominantly female occupations, and so the men in these occupations had more diverse options available to them. Approximately three quarters of workers are employed in predominantly male or predominantly female occupations $(78.7 \%$ of working women, $73.3 \%$ of working men).

Table 1

Breakdown of Labour Force by Degree to Which Occupations are Female or Male, Quebec, 1991-2006 


\begin{tabular}{|c|c|c|c|c|c|c|}
\hline \multirow[t]{2}{*}{ Women } & \multicolumn{2}{|c|}{2006} & \multicolumn{2}{|c|}{2001} & \multicolumn{2}{|c|}{1991} \\
\hline & $\begin{array}{l}\text { Number of } \\
\text { occupations }\end{array}$ & $\begin{array}{l}\% \text { of labour } \\
\text { force }\end{array}$ & $\begin{array}{l}\text { Number of } \\
\text { occupations }\end{array}$ & $\begin{array}{l}\% \text { of labour } \\
\text { force }\end{array}$ & $\begin{array}{l}\text { Number of } \\
\text { occupations }\end{array}$ & $\begin{array}{l}\% \text { of labour } \\
\text { force }\end{array}$ \\
\hline $\begin{array}{c}\text { In female or } \\
\text { predominantly female } \\
\text { occupations }\end{array}$ & 174 & 78.7 & 170 & 77.7 & 152 & 79.2 \\
\hline In male occupations & 125 & 15.4 & 115 & 16.6 & 109 & 14.8 \\
\hline $\begin{array}{l}\text { In predominantly male } \\
\text { occupations }\end{array}$ & 221 & 6 & 221 & 5.7 & 245 & 6 \\
\hline Total & 520 & 100 & 506 & 100 & 506 & 100 \\
\hline \multicolumn{7}{|l|}{ Men } \\
\hline $\begin{array}{l}\text { In male or predominantly } \\
\text { male occupations }\end{array}$ & 347 & 73.3 & 337 & 75.5 & 353 & 77.3 \\
\hline In female occupations & 102 & 20.3 & 103 & 18.2 & 92 & 16.5 \\
\hline $\begin{array}{l}\text { In predominantly female } \\
\text { occupations }\end{array}$ & 71 & 6.4 & 66 & 6.3 & 61 & 6.2 \\
\hline Total & 520 & 100 & 506 & 100 & 506 & 100 \\
\hline
\end{tabular}

Source: Statistics Canada, 2001 Census (97F0012XCB01022). Compilations by the Institut de la statistique du Québec.

http://www.stat.gouv.qc.ca/donstat/societe/march_travl_remnr/cat_profs_sectr_activ/professions/rece ns2001/tabwebprof_juin03-4.htm

In 2006, women were working in 221 occupations where there was a very high concentration of men. Conversely, men were to be found in 71 occupations with a very high proportion of women, all over the economy.

In this article I will show two things: first, that the labour market is still very divided with respect to gender and, second, that the material impact of this division on pay gap differs sharply by level of education. Among occupations that require the least education, women pay a very high price for this gender based division of employment. In contrast with occupations where more education is needed, those requiring the least education show a huge difference in wages according to whether they are predominantly male or predominantly female. This difference is a widespread phenomenon that favours so-called male occupations. The corresponding pay gap, in favour of men, in occupations requiring a 
high school diploma (Secondary V in Quebec) ${ }^{1}$ or less, is shrinking only slightly, whereas the gaps between men and women in occupations requiring more education are clearly closing. I will examine three options for action that, at present, offer little hope for improvement. Indeed, this problem still affects approximately 500,000 women, after 25 years of equal access programs and close to 15 years of implementation of the Pay Equity Act, that is supposed to be an international model of the type... (Chicha, 2006). In fact, most studies of the factors of success / failure of pay equity programs focus on unionization and organization size (England \& Gad, 2002) but not on the effect of job segregation combined to level of education of workers. The following demonstration shows that we should pay attention to that latter factor.

\section{PAY AND EMPLOYMENT EQUITY LEGISLATION IN QUEBEC AND CANADA}

\section{Employment equity}

The Government of Quebec has never adopted a proactive legislation regarding employment equity in the private sector, aside from requiring organizations that solicit contracts and subsidies from them to hire women, under "contractual obligation".

Only the Canadian government has enacted a proactive approach in the private sector, since 1985, in the case of organizations that employ 100 employees or more, under the Employment Equity Act (RSC (1995) c. 44.) This law is covering 1,1 million employees in 2008, that means a very small proportion (7\%) of the 14,4 millions Canadian workers. Moreover, the federal government imposes a "contractual obligation" as well.

Systemic discrimination is the fundamental concept behind the entire Quebec legal apparatus in terms of equity. Systemic discrimination is neither explicit, nor voluntary, neither conscious nor intentional. It is often the result of a management system that is based on a certain number of presuppositions, most often implicit, with respect to various groups and includes practices and traditions that perpetuate a situation of inequality with respect to the members of the target groups. Systemic discrimination involves discrimination that is built into employment systems, often unintentionally. Such systems always have an adverse impact on one group (i.e., women) compared to another (men); they may reflect old social values (e.g., men are breadwinners and should be paid more).

1. In Quebec, high school finishes upon completion of Secondary V (the equivalent of Grade 11 in the rest of Canada). 
The necessary criterion to establish for systemic discrimination refers to the "under-use" of the members of the four target groups: women, members of cultural communities, people with disabilities, and Native People (CDPDJQ, 2003a, p. 9; CDPDJQ, 2003b, p. 10; Legault, 2002 , p. 76). The members of the target groups are under used when their numbers in a given job, in a given organization are less than their availability rate on the job market. When this threshold is established, the employer may practice preferential hiring or promotion for the members of the target groups when they have the same qualifications as the other candidates, until the group has the same representation rate in the organization as this availability rate on the job market. Affirmative action programs aim essentially at increasing the representation of the members of the target groups and at breaking down the sexual segregation of jobs by providing access to all types of jobs.

\section{Pay equity}

In Canada and in other parts of North America as well, pay equity, also known as "fair wages" or "fair pay," is a means to redress a particular kind of intraorganization gender based wage discrimination that results from a combination of gender based occupational segregation and the underpayment of women's work. The need for pay equity is indeed premised on the *conclusion that female jobs have been undervalued and underpaid because they have been performed primarily by women (or the overcrowding hypothesis, Alksnis, Desmarais \& Curtis, 2008; Bergmann, 1971,1974; Sorensen, 1990). Unlike employment equity, pay equity focuses on gender and not on race, disability or any other discriminating status. A key lesson learned from complaint-based, human rights- style approach is that they are not as effective for redressing discrimination built into compensation systems as a proactive approach (Beeman, 2004). Quebec, the first jurisdiction to require pay equity (1976), changed its initial complaint-based approach to a proactive one in 1996. It has now been in force for close to 15 years. The basic three-step pay equity process includes: defining female and male jobs, using a gender-neutral job evaluation system to assess the value of female and male jobs, and using a method to determine fair wages for female jobs that are of comparable value to male jobs.

Nearly all of the 14 Canadian jurisdictions are involved with pay equity: (1) federal public service, federal Crown corporations, private firms crossing provincial boundaries (banking, communication, and transportation industries); 2) nine of ten provincial governments, which covers provincial public service, broader public sector organizations (e.g., schools, hospitals), and private firms operating within their provincial boundaries; 3) three territories. Private sector organizations are covered with proactive legislation in two jurisdictions: Ontario since 1988 and Quebec since 1996. (Weiner, 2002, p. S 104-5). 
Pay equity in Canada takes place within a single organization (Quebec's Pay Equity Act, $L R Q$, ch. E-12.001, section 1) as compared to countries with broader, more centralized wage-setting mechanisms (e.g., Australia). Gender-neutral job evaluation is the key to pay equity. Though compatible with pay equity, in reality, job-evaluation systems either incorporated gender bias or were used in a gender biased manner. Pay (and employment) equity are aimed at redressing systemic gendered discrimination in wage setting. Job's value is defined in terms of skill, effort, responsibility, and working conditions. The aggregate value of female jobs is compared to the aggregate value of a corresponding male job - or to the corresponding point on a jobs' wages line.

Pay equity is directed at redressing underpayment of women's work while temporarily taking occupational segregation for granted (Armstrong \& Cornish 1997). However, it is theoretically possible that over time, the higher wages that become associated with female jobs because of pay equity could attract a higher proportion of men to the occupation:

As long as women's jobs are paid fairly given their value, pay equity is achieved even though occupational segregation continues. Employment equity, on the other hand, is designed to reduce occupational segregation among traditional male jobs by removing the barriers that have kept women (and other designated groups) out. Employment equity "accepts" the wages associated with traditionally female jobs, that is, it is unconcerned that female jobs may be underpaid relative to their value. (Weiner, 2002, p. S 102)

Some feel that pay equity is not needed because employment equity will remove the barriers that prevent women from moving into higher paid male jobs. Such a view makes two inappropriate assumptions:

First, that all men's jobs pay more than all women's jobs; janitors compared to nurses show that this is not true. Second, that all women will move into higher level male jobs; this denies the continuing need for what have traditionally been female jobs. Pay equity is needed because of the presence of both occupational segregation and the underpayment of women's work (Weiner, 2002, p. S 102).

*True, nurses are better paid than janitors are; but they are different level jobs, so one could say that this argument is not conclusive. We will see here that among jobs requiring a same lower level of education, men's jobs are generally better paid than women's. That being said, there are various types of gender wage gaps, not all of those being addressed by pay equity legislations:

- Men working in higher valued jobs than women (segregation in employment, employment and pay inequity),

- Man and women working in substantially the same jobs, but men work in higher-wage industries (idem),

- Men and women working in substantially the same jobs for the same employer and

- men have higher human capital or productivity, or

- men are paid more (unequal pay for equal work, direct discrimination) 
- Men and women working in equally valued job for the same employer and men are paid more (discrimination that pay equity is designed to redress) (Weiner, 2002, p. S 103).

We will here focus on the first source of pay inequity that pay equity legislation fails to address and eradicate (men working in higher valued jobs than women). Baker and Fortin (1999) have looked at the relationship between the proportion of men and women in an occupation and their pay and shown that in the US, there is a negative relationship between hourly wages and the proportion of women in an occupation (so concluded Sorensen, 1990). This is related to pay equity since the proportion of women in an occupation is expected to be related to wages at the level of the firm. Nan Weiner, a Canadian expert, asserts that this latter relationship "does not exist in Canada" (Weiner, 2002, p. S 113). An in-depth analysis of jobs for which fewer qualifications are required shows that things are not that simple.

\section{LABOUR FORCE CONCENTRATION OF WOMEN AND MEN}

Is the situation changing in terms of gendered workforce concentration? Some underlying trends are stable, as can be seen from a previous paper (Legault, 2010). The top 10 occupations in 2006 were among the top 20 in 2001 and 1991, with one exception. The top three female occupations remained the same: secretary (98\% women), sales clerk (56.7\%) and cashier (86.1\%); sales clerk and cashier are relatively unskilled occupations.

If we broaden the scope of our study to include the top 50 occupations for women in 2006, we obtain a range that encompasses two thirds of working women. If, from this group, we take occupations where no more than a high school diploma is required, it can be seen (Table 2) that a third of the women in the labour force work in 20 occupations that have a very high percentage of female employees.

Table 2

Selection of occupations where no more than a high school diploma is required among top 50 for women in 2006, Quebec

\begin{tabular}{rlrrr}
\hline Rank & \multicolumn{1}{c}{ Occupational structure NOC-S 2006 } & $\begin{array}{r}\text { Labour force } \\
\text { (15 and over) }\end{array}$ & $\begin{array}{r}\text { \% of female } \\
\text { labour force }\end{array}$ & \% women \\
1 & Secretaries (except legal and medical) & 99,105 & 5.4 & 98 \\
3 & Cashiers & 70,425 & 3.8 & 86.1 \\
5 & General office clerks & 55,740 & 3.0 & 87.2 \\
8 & Accounting and related clerks & 45,250 & 2.4 & 84.8 \\
9 & Food and beverage servers & 41,605 & 2.2 & 76.4 \\
\hline
\end{tabular}




\begin{tabular}{lllll}
\hline 10 & Nurse aides, orderlies and patient service associates & 41,245 & 2.2 & 81.4 \\
16 & Receptionists and switchboard operators & 24,940 & 1.3 & 87.8 \\
17 & Customer service, information and related clerks & 24,065 & 1.3 & 63.5 \\
19 & Hairstylists and barbers & 22,225 & 1.2 & 85.2 \\
20 & Customer service representatives in financial services & 21,300 & 1.2 & 88.3 \\
23 & Industrial sewing machine operators & 16,920 & 0.9 & 89.8 \\
24 & Visiting homemakers, housekeepers and related occupations & 14,920 & 0.8 & 86.6 \\
27 & Elementary and secondary school teacher assistants & 12,985 & 0.7 & 83.2 \\
29 & Administrative clerks & 12,755 & 0.7 & 74.3 \\
31 & Licensed practical nurses & 11,895 & 0.6 & 91.4 \\
32 & Other assisting occupations in support of health services & 11,805 & 0.6 & 85.2 \\
33 & Babysitters, nannies and parents' helpers & 11,190 & 0.6 & 96.6 \\
34 & Estheticians, electrologists and related occupations & 10,895 & 0.6 & 96 \\
37 & Bookkeepers & 9,765 & 0.5 & 80.4 \\
& Total (\% women: weighted average) & 559,030 & 30.2 & 86.5 \\
& Total for top 50 occupations (\% women: weighted average) & $1,222,945$ & 66.1 & 67.7 \\
& Total for 520 occupations & $1,849,195$ & 100 & 47.1 \\
\hline
\end{tabular}

Source: Special compilation by the ISQ

In 2006, women were still underrepresented in the less-skilled, predominantly male occupations: truck driver, automotive service technician, carpenter, janitor, material handler, delivery driver and construction labourer (Legault, 2010). Construction industry occupations in general are still predominantly male (98.8\% men; Legault \& Danvoye, 2007, p. 64).

Women have made noteworthy progress among bus drivers, subway operators and other transit operators (proportion of jobs in these occupations held by women rising from $21.2 \%$ in 1991 to $26.1 \%$ in 2001) and among technical sales specialists (proportion up from 21.5\% in 1991 to $27.4 \%$ in 2001) - which pushed these two occupations from predominantly male to just male - and among shippers and receivers (from $17.6 \%$ to $22.3 \%$ ), often thanks to affirmative action measures, at the very least for bus drivers and subway operators, due to city governments' legal liabilities. 
Yet, overall, it can be seen that there is a higher proportion of men than women in the manufacturing industries, while there are more women in the service industries. Even within the service sector, there are still some gender divisions, with more men than women employed in the transportation industry, for instance.

If, as we did for women, we broaden our scope to include the top 100 occupations for men in 2006, we arrive at a range that encompasses virtually two thirds of the men in the labour force. If, from this group, we take occupations that require no more than a high school diploma, it can be seen (Table 3 ) that $28.2 \%$ of working men are employed in 37 occupations where the percentage of male workers is very high.

\section{Table 3}

\section{Selection of Occupations Where no More than a High School Diploma is Required among} Top 100 for Men in 2006, Quebec

\begin{tabular}{|c|c|c|c|c|}
\hline Rank & Occupational structure NOC-S 2006 & $\begin{array}{l}\text { Labour force } \\
\text { (15 and over) }\end{array}$ & $\begin{array}{l}\% \text { of male } \\
\text { labour force }\end{array}$ & $\%$ men \\
\hline 2 & Truck drivers & 63,385 & 3 & 96.5 \\
\hline 4 & $\begin{array}{l}\text { Automotive service technicians, truck and bus mechanics and } \\
\text { mechanical repairers }\end{array}$ & 37,630 & 1.8 & 98.4 \\
\hline 5 & Carpenters & 34,600 & 1.7 & 98.7 \\
\hline 6 & Janitors, caretakers and building superintendents & 34,170 & 1.6 & 82.1 \\
\hline 7 & Material handlers & 33,210 & 1.6 & 89.1 \\
\hline 8 & Delivery and courier service drivers & 30,980 & 1.5 & 92.8 \\
\hline 10 & Construction trades helpers and labourers & 27,935 & 1.3 & 94.1 \\
\hline 15 & Shippers and receivers & 24,450 & 1.2 & 75.2 \\
\hline 18 & Welders and related machine operators & 22,995 & 1.1 & 95.8 \\
\hline 20 & Security guards and related occupations & 20,790 & 1 & 75.3 \\
\hline 21 & $\begin{array}{l}\text { Construction millwrights and industrial mechanics (except } \\
\text { textile) }\end{array}$ & 20,660 & 1 & 98.2 \\
\hline 28 & Heavy equipment operators (except crane) & 16,120 & 0.8 & 98.7 \\
\hline 29 & Machinists and machining and tooling inspectors & 16,030 & 0.8 & 94.5 \\
\hline 30 & Landscaping and grounds maintenance labourers & 15,375 & 0.7 & 88.3 \\
\hline 31 & Labourers in wood, pulp and paper processing & 15,055 & 0.7 & 87.2 \\
\hline 33 & General farm workers & 14,570 & 0.7 & 71.4 \\
\hline
\end{tabular}




\begin{tabular}{|c|c|c|c|c|}
\hline 34 & Electricians (except industrial and power system) & 14,400 & 0.7 & 98.5 \\
\hline 40 & Storekeepers and parts clerks & 12,020 & 0.6 & 86.8 \\
\hline 44 & Public works and maintenance labourers & 10,875 & 0.5 & 86.7 \\
\hline 51 & Taxi and limousine drivers and chauffeurs & 9,555 & 0.5 & 92.9 \\
\hline 55 & Plumbers & 8,765 & 0.4 & 98.3 \\
\hline 58 & Motor vehicle body repairers & 8,550 & 0.4 & 97.3 \\
\hline 67 & Printing press operators & 7,540 & 0.4 & 85.5 \\
\hline 70 & Furniture and fixture assemblers and inspectors & 7,435 & 0.4 & 79.3 \\
\hline 71 & Heavy-duty equipment mechanics & 7,415 & 0.4 & 98.4 \\
\hline 73 & Cabinetmakers & 7,305 & 0.4 & 89.9 \\
\hline 74 & Residential and commercial installers and servicers & 7,215 & 0.3 & 95.2 \\
\hline 78 & $\begin{array}{l}\text { Butchers, meat cutters and fishmongers - retail and } \\
\text { wholesale }\end{array}$ & 6,915 & 0.3 & 84 \\
\hline 81 & Specialized cleaners & 6,495 & 0.3 & 87.8 \\
\hline 82 & Chefs & 6,455 & 0.3 & 76.3 \\
\hline 83 & Residential home builders and renovators & 6,220 & 0.3 & 97 \\
\hline 90 & $\begin{array}{l}\text { Process control and machine operators, food and beverage } \\
\text { processing }\end{array}$ & 5,485 & 0.3 & 70.3 \\
\hline 91 & Plasterers, drywall installers and finishers and lathers & 5,475 & 0.3 & 93.8 \\
\hline 94 & Letter carriers & 5,255 & 0.3 & 68.8 \\
\hline 98 & Sawmill machine operators & 4,950 & 0.2 & 94.3 \\
\hline 99 & Service station attendants & 4,750 & 0.2 & 71.7 \\
\hline \multirow[t]{4}{*}{100} & Bricklayers & 4,730 & 0.2 & 99 \\
\hline & Total (\% men: weighted average) & 585,760 & 28.2 & 90.5 \\
\hline & Total for top 100 occupations (\% men: weighted average) & $1,415,485$ & 68 & 58.1 \\
\hline & Total for 520 occupations & $2,080,075$ & 100 & 52.9 \\
\hline
\end{tabular}

Source: Special compilation by the ISQ

In other words, if, from all occupations, we first take the top ones for women and for men, so that we have around two thirds of male and female workers, and if we then look at 
occupations that

- require no more than a high school diploma and

- are predominantly male or female, in other words, highly gender-divided,

then it can be seen that a third of working women are employed in 20 occupations having a very high proportion of female workers (weighted average of $86.5 \%$ ), and that $28.2 \%$ of men work in 37 occupations having a very high proportion of male workers (weighted average of $90.5 \%$ ). This means that around a third of men and women work in predominantly male or predominantly female occupations requiring no more than a high school diploma.

Does gender division, or gender based concentration of workers, affect all occupations in the economy to the same degree? Occupational sex segregation is well distributed throughout the economy and is not restricted to occupations requiring lower levels of education. If, from the top 50 occupations for women and the top 100 occupations for men, we aggregate those requiring a junior college diploma or university degree and involving managerial duties this time without choosing those with the highest proportion of male or female workers and without excluding mixed workforce occupations - and those requiring high school diploma or less, and compute the average male/female concentration, we obtain relatively comparable weighted average proportions of women and men for the four groups (Table 4).

\section{Table 4}

Concentration by Sex and by Level of Education Required for Occupation, Quebec, 2006

\begin{tabular}{|l|c|c|}
\hline \multicolumn{1}{|c|}{ Occupations } & Top 50 among women & Top 100 among men \\
\hline $\begin{array}{l}\text { Requiring a junior college or university degree, and } \\
\text { involving managerial duties }\end{array}$ & $75.8 \%$ & $73.4 \%$ \\
\hline Requiring high school diploma or less & $72.8 \%$ & $69.3 \%$ \\
\hline
\end{tabular}

Source: Special compilation by the ISQ.

Experts tend to assert that "Gender gaps are closing in terms of education, hours and days worked" (England \& Gad, 2002, p. 292) and this is a fact. But, still, education and hours of work being equal for given social groups, there is gendered concentration in many occupations, all over the economy. And while the concentration of one gender or the other in an occupation is not restricted to jobs requiring fewer qualifications, the consequences of such segregation are much more serious in these jobs. According to the "crowding hypothesis", we're supposed to observe the following sequence of facts: Given that women are crowded into some occupations, typically referred to as "women's work", it in turn reduces their wage:

For simplification, this model assumes that women and men have equal abilities and thus without discrimination they would be paid equally. Hence, it predicts that because of 
discrimination women and men are segregated into different occupations and that those doing "women's work" earn less than those doing "men's work" even though all workers are equally well qualified for both jobs. (Sorensen, 1990, p. 56)

In other words, we are supposed to find that the proportion of women in a worker's occupation has a significantly negative effect on his/her earnings.

Reading contemporary data leads to slightly different conclusions; in that matter, progress in women's earnings is noticeable in jobs requiring education, refuting the crowding hypothesis; however, the crowding hypothesis is still confirmed as there is far more inertia in lesseducated job sectors. In other words, the consequences of a lower level of education on wages are not the same for women and men, as we shall see.

\section{OCCUPATIONAL SEX SEGREGATION HAS A VERY SIGNIFICANT MATERIAL IMPACT ON THE LESS EDUCATED ${ }^{2}$}

\section{The General Wage Gap: Comparing hourly rates of pay}

In industrialized societies in general, the average rates of pay - whether hourly, weekly or annual - for men are higher than those for women; only the size of the gap varies with the pay period considered.

The advantage of comparing annual compensation is that it represents actual employment income available to workers, taking into account the actual duration of paid work, excluding periods of unemployment, time between temporary jobs, and part-time work, but including overtime hours. On the other hand, it does not provide a precise indication of the value of work in the marketplace, as variations in the length of time worked confuse the picture.

Weekly compensation is closer to representing the value of work in the marketplace, as it excludes confounding factors such as periods without employment (due to temporary job status or to periods of unemployment during the year), but is nevertheless affected by two other confounding factors: work pattern (full time or part time) and overtime hours.

Looking at hourly compensation has the advantage of not introducing any confounding factors such as work pattern (full time, part time), employment status (permanent, temporary), periods without employment or overtime hours.

2 I have divided the working population in 4 groups that remain constant throughout the study: No high school diploma (less than high school diploma), High school diploma (completed), Postsecondary (but no university degree), University degree. The term least educated refers to the No high school diploma group, while the term less educated refers to both No high school diploma and High school diploma. 
The gap between men's and women's hourly pay is always less than the gap between their weekly or annual pay. Weekly and annual rates offer a more accurate picture of real income, as they take into account the actual time worked. On the other hand, the hourly rate tells us more about market value, and that is why I have chosen to focus on hourly rates here. So please keep in mind that this represents the smallest pay gap.

\section{A narrowing gender pay gap in general...}

In Quebec, men's hourly pay rate was greater than women's throughout the period 19982008, but the difference shrank by 3.8 percentage points (Table 5 ). While hourly rates rose for both sexes over that time, the increase was higher for women $(33.2 \%)$ than for men (27.4\%). This consistent trend can be explained by the propensity of employers to invest in training and raise pay when employees are more stably employed.

\section{Table 5}

Gaps in hourly pay between men and women, Quebec, 1998-2008

\begin{tabular}{ccccc}
\hline Hourly & 1998 & $\mathbf{2 0 0 3}$ & $\mathbf{2 0 0 8}$ & $\begin{array}{c}\text { Change } \\
1998-2008\end{array}$ \\
All men & $\$ 16.79$ & $\$ 18.82$ & $\$ 21.39$ & $+27.4 \%$ \\
All women & $\$ 14.01$ & $\$ 15.93$ & $\$ 18.65$ & $+33.2 \%$ \\
Gap men-women & $\$ 2.78$ & $\$ 2.89$ & $\$ 2.74$ & \\
Gap in \% & $16.6 \%$ & $15.4 \%$ & $12.8 \%$ & $-3.8 \mathrm{pp}$ \\
\hline
\end{tabular}

Source: Special compilation by the ISQ

The gaps are narrowing and the general trend is toward equity, but here we're talking about an aggregate gap.

But what happens to the difference between men's and women's rates of pay if the level of education required for jobs is taken into account?

Extensive studies of the relationship between education and pay, both in the general population and among women in particular, have shown how the gap in pay between men and women can be reduced if the gap in education is reduced, and the same applies for skills acquired outside of the educational system (Blau, Ferber \& Winkler, 2002; Blau \& Kahn, 2000; Drolet, 2001; Gunderson, 2006; Gunderson \& Muszynski 1990; O'Neill \& Polachek, 1993). The specialized vocational training programs for trades are part of the problem in that point of view, as they are informally, but no less efficiently, closed to women. According to the theory of human capital, a worker's level of pay can be partly explained by his or her productivity factors, including education and skills. In other words, one portion of 
the gendered wage gap is attributable to differences in the wage-determining characteristics of women and men as age, education and training (Gunderson, 1998).

I have divided the working population into four groups that remain constant throughout the study: no high school diploma (less than a high school diploma), high school diploma (completed), postsecondary study (but no university degree), and university degree. The term "least educated" refers to the no high school diploma group, while the term "less educated" refers to both the no high school diploma group and the high school diploma group.

Table 6 shows that while women's hourly rates of pay are lower than men's for all levels of education, women's rates rose more than men's over the period from 1998 to 2008.

Table 6

Hourly pay, by sex and level of education, Quebec, 1998-2008 (current dollars)

\begin{tabular}{lcccccccc}
\hline \multicolumn{1}{c}{ Year } & \multicolumn{2}{c}{ No high school diploma } & \multicolumn{2}{c}{ High school diploma } & \multicolumn{2}{c}{ Postsecondary } & \multicolumn{2}{c}{ University degree } \\
& M & W & M & W & M & W & M & W \\
1998 & $\$ 13.08$ & $\$ 9.75$ & $\$ 15.22$ & $\$ 12.27$ & $\$ 16.15$ & $\$ 13.63$ & $\$ 24.04$ & $\$ 20.16$ \\
2008 & $\$ 15.73$ & $\$ 11.93$ & $\$ 18.88$ & $\$ 15.82$ & $\$ 20.76$ & $\$ 17.69$ & $\$ 29.97$ & $\$ 25.94$ \\
\hline $\begin{array}{l}\text { Change } \\
1998-2008\end{array}$ & $+20.3 \%$ & $+22.3 \%$ & $+24 \%$ & $+29 \%$ & $+28.5 \%$ & $+30 \%$ & $+24.7 \%$ & $+28.7 \%$ \\
\hline
\end{tabular}

Source: Special compilation by the ISQ.

\section{... But the Least Educated Female Workers still trail behind}

Despite the solid findings of these studies, they all ignore one obvious fact: there can be a huge difference between the pay levels of predominantly male and predominantly female occupations requiring the same level of education. In other words, the return on education investment can differ for men and women, and the return on lack of education as well. The effect of low education on pay is not the same for women and men. This runs counter to widespread myths according to which the wage gap is closing at the lower and middle salary ranges, while increasing at the higher salary ranges... (Leck et al., 1995).

In Table 7, it can be seen that the ratio of women's average hourly rate to men's average hourly rate varies with level of education. The lowest ratio for women is among the leasteducated workers, where women earn just $75.8 \%$ of what men with the same level of schooling earn.

\section{Table 7}


Women's/Men's ratio of hourly rate of pay, by level of education, Quebec, 1998-2008

\begin{tabular}{lcc}
\hline \multicolumn{1}{c}{ Level of education } & 1998 & \\
\hline No high school diploma & 74.5 & 75.8 \\
High school diploma & 80.6 & 83.8 \\
Postsecondary & 84.4 & 85.2 \\
\hline University degree & 83.9 & 86.5 \\
\hline
\end{tabular}

Source: Special compilation by the ISQ.

Chart 1 illustrates the percentage differences between the hourly rates of pay of men and women (in men's favour, in all cases) by level of education (no high school diploma, high school diploma, junior college or postsecondary, and university degree) between 1997 and 2008. Trend lines (linear regression) through the scatters of distinct points for each level of education indicate the general trend; they take into account all the points, even extreme values.

The chart clearly shows a downward trend in the mean differences between men's and women's average hourly rates of pay, between 1997 and 2008, for all levels of education combined (from $15.77 \%$ to $12.81 \%$ ). The smallest differences were among the better educated and indicated a similar decline (from $16.12 \%$ to $14.79 \%$ for the junior college/postsecondary group, and from $13.58 \%$ to $13.45 \%$ for the university degree category). The differences for high school graduates were greater, but they fell, too (from $18.22 \%$ to $16.21 \%$ ).

\section{A growing gender pay gap inversely proportional to education}

What is striking, however, is the huge distance between the gender gap of men and women having no high school diploma and that of men and women in the most educated group. Furthermore, the gap for the least educated shows only a slight downward trend (from $25.83 \%$ to $24.16 \%$ ), while others have a clear downward trend.

\section{Chart 1}

Percentage differences in average hourly compensation of men and women (employees) by level of education, annual means, Quebec, 1997-2008 (in current dollars) 


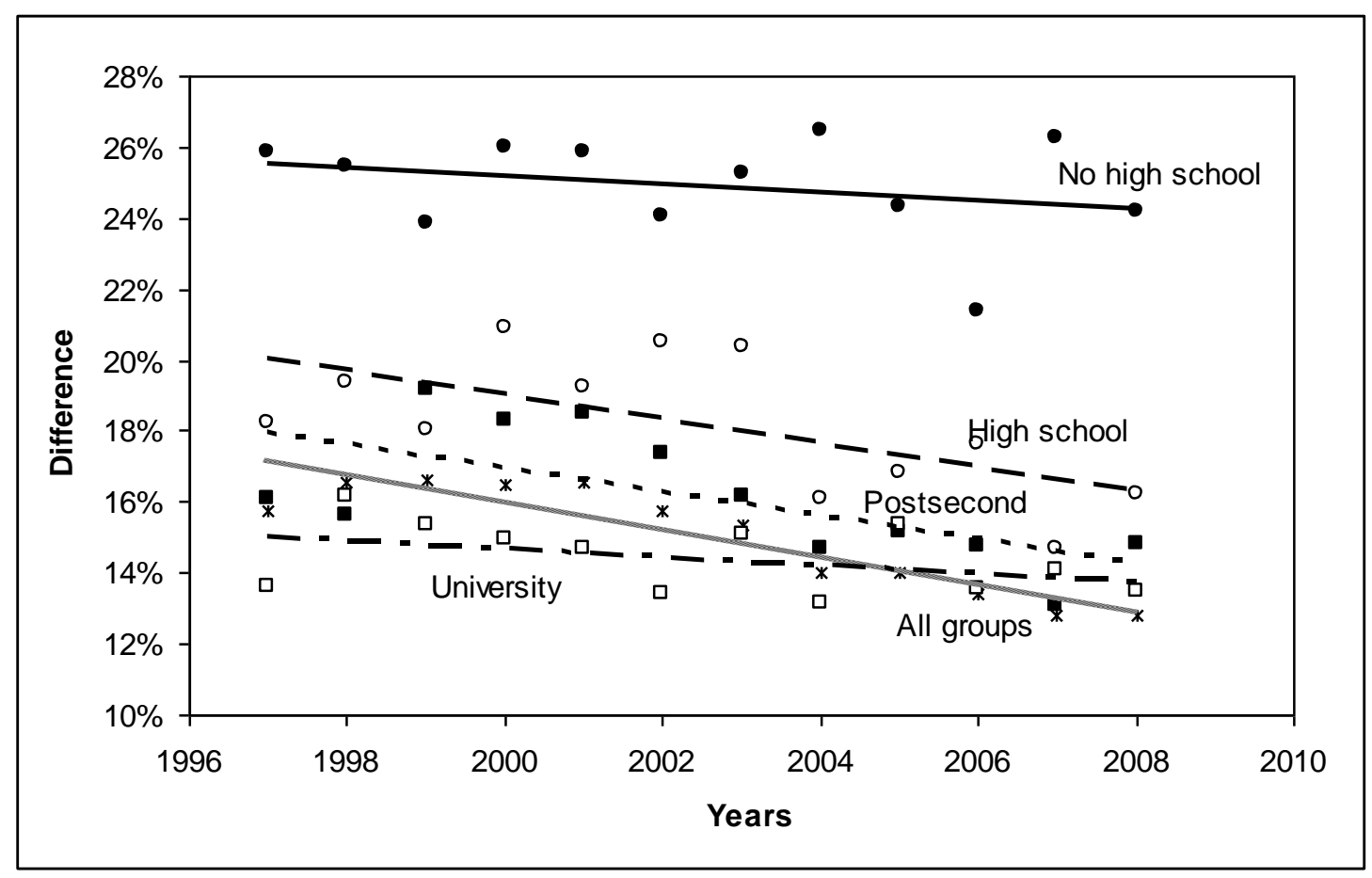

Source: Statistics Canada, Labour Force Survey. Processing: Institut de la statistique du Québec, Direction du travail et de la rémunération. February 14, 2008, and August 17, 2009. Average hourly compensation excludes the self-employed and concerns a worker's primary job, the one in which he or she works the greatest number of hours, for workers who hold down more than one job.

\section{Not even a downward trend in weekly gender pay gap among the least educated}

What happens if we examine the same differences between men and women, but this time in terms of average weekly pay? Chart 2 below shows the percentage differences in weekly rates of pay between men and women, by level of education.

It is clear from the chart that the average differences between men and women, between 1997 and 2008, for all levels of education taken together, were much higher, but were still following a downward trend (from $28.21 \%$ to $23.07 \%$ ). The smallest differences were among the most educated and showed the same falling trend (from 29.03\% to $26.06 \%$ for junior college/postsecondary education, and from $24.04 \%$ to $19.76 \%$ for university graduates). Differences were greater for those with only a high school diploma, but they too were dropping (from $29.62 \%$ to $26.81 \%$ ).

Yet what is even more striking in this case is the huge distance between the gender gap of men and women having no high school diploma and that of men and women in the most 
educated category. Moreover, the gap for the least educated does not appear to be falling, but rather remaining more or less stable (from $39.39 \%$ to $39.16 \%$ ).

Chart 2

Percentage differences in average weekly compensation of men and women (employees) by level of education, annual means, Quebec, 1997-2008 (in current dollars)

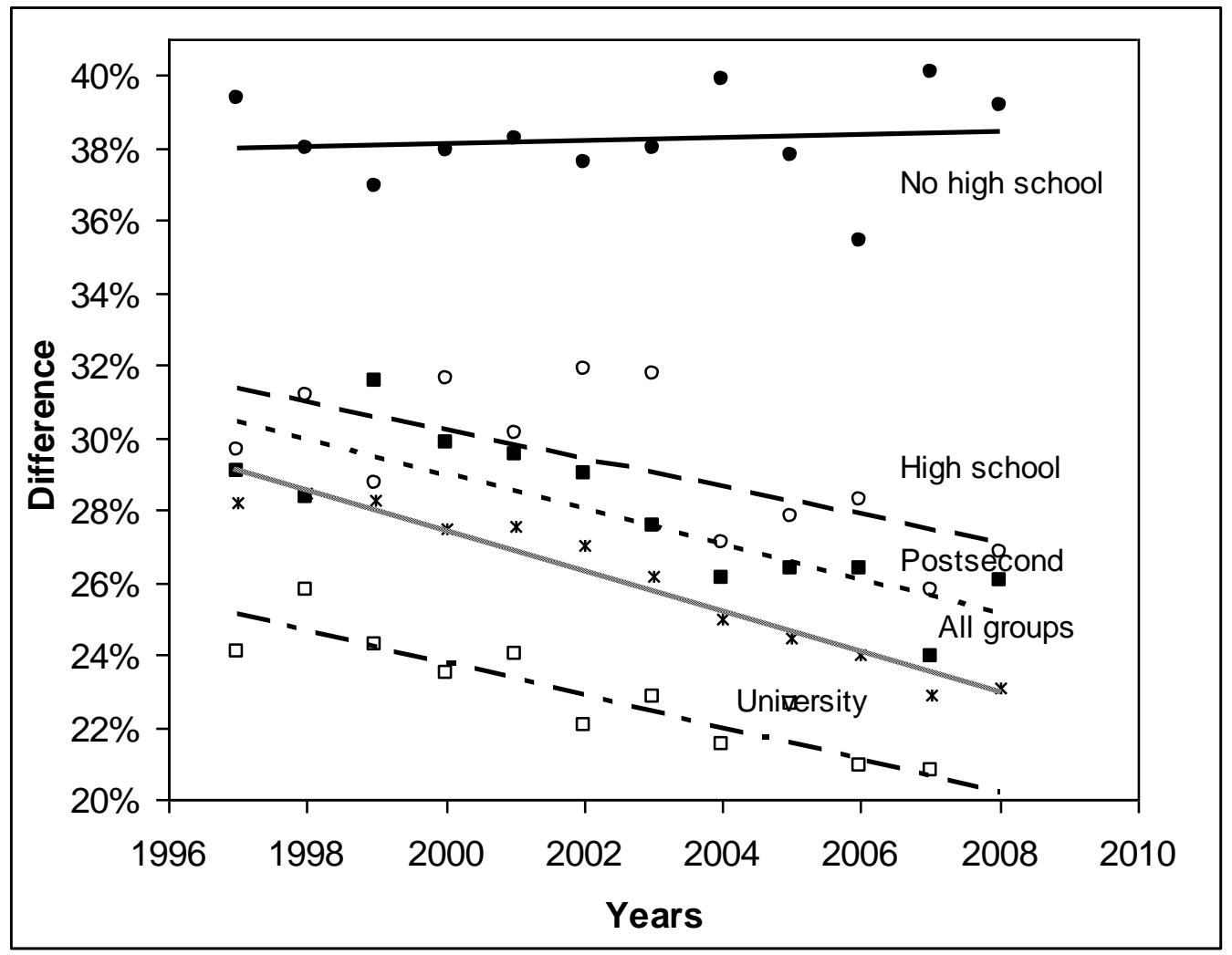

Source: Statistics Canada, Labour Force Survey. Processing: Institut de la statistique du Québec, Direction du travail et de la rémunération. February 14, 2008, and August 17, 2009. Average weekly compensation is for employees only. It concerns a worker's primary job, the one in which he or she works the greatest number of hours, for workers who hold down more than one job.

In both cases, it should be noted that the pay differences in favour of men, while generally declining, are much higher and more stable among the least educated than among junior college graduates and university graduates.

While the less educated women predominantly hold down the lowest-paid jobs in the service sector: sales clerks, cashiers, servers, office clerks and nurse aides, as we saw earlier, the less educated men occupy the better-paid jobs: construction trades, truck drivers, and automotive service technicians, truck and bus mechanics and mechanical repairers.

In other words, for the same level of education, the predominantly male occupations are much better paid than the predominantly female occupations. It is also in these jobs that 
occupational segregation by sex is the most stable and where equal access programs are the most ineffective, as we will see below.

\section{4,000 working women affected}

How many women are affected by this situation? In 2008 , women who had no high school diploma made up $11.2 \%$ of the labour force, whereas those who had graduated from high school accounted for $15.4 \%$. All in all, 494,000 working women and 682,000 men were in these two groups. Is there a decline in the size of the aggregate group of women with a high school education or less? Yes, but it is slow, as can be seen from Chart 3 below, in which I have combined high school graduates and non-graduates together.

\section{Chart 3}

\section{Percentage of men and women with high school diplomas or less, Quebec, 1997-2008}

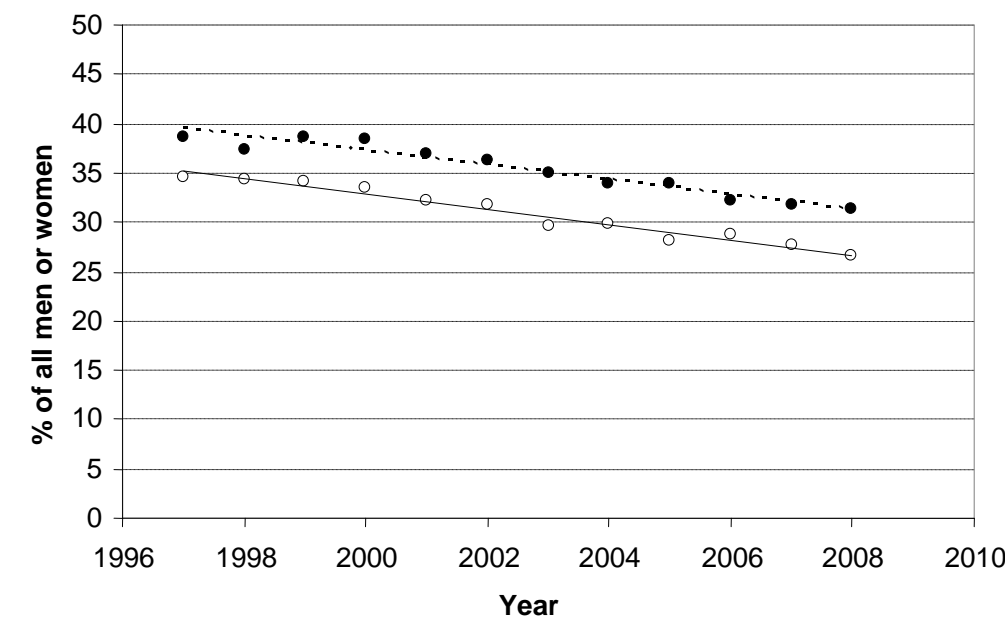

Source: 2006: Special compilation by the ISQ.

Of course, pay is only one aspect of job quality, nor is it the sole criterion on which job seekers base their choice, as they must take a number of different factors into consideration. I could also discuss job quality on the basis of gender and level of education: the Institut de la statistique du Québec has developed a typology of job quality that can be used to compare all salaried jobs (self-employed workers are excluded) within a given economic territory with one another and over time, and to compare groups of workers having specific characteristics (sex, age, unionized status, ethnic origin) from the point of view of the quality of their jobs, based on the result of a combined index of four indicators: pay, qualifications, 
stability and working hours (Cloutier, 2008). The results are simply just the same: femaledominated jobs requiring high school diploma or less have low scores according to this index, while male-dominated ones have higher scores ${ }^{3}$.

To sum up, the ISQ's job quality typology shows a gap, to the disadvantage of women, in the proportions of men and women in good jobs, although the gap narrowed between 1997 and 2007. When the men's and women's groups are broken down by level of education (highest diploma/degree earned), it can be seen that the gap chiefly affects the less educated women. In the labour force that has no high school diploma, women are at most disadvantage, while they are at a distinct disadvantage among the high school diploma group. The gap between women and men has remained roughly stable, and the only consolation is to be found in the fact that the total number of men and women with this level of education has declined, although the group remains large. Lastly, in the labour force that has a university degree, the gap between women and men is narrowing. While the total number of men and women in this latter group is rising, the number of women is increasing more than the number of men.

\section{WHY IS THIS INEQUITY A PUBLIC POLICY ISSUE?}

\section{The Vicious Circle of Poverty}

The situation of women with little education is of particular concern, because their chances of getting ahead are minimal. It is hard for adults in low-paying jobs to move up the employment ladder. One U.S. study has shown that, over a six-year period beginning in the early 1990 s that saw very strong economic growth, only $27 \%$ of these adults managed to increase their earnings and rise above, on a sustainable basis, the poverty line defined for a family of four (Hölzer, 2004). Another, more recent U.S. research project, using data from the Panel Study on Income Dynamics, reached a similar conclusion. Investigating low-wage workers over the period 1995-2001, the researchers discovered that $6 \%$ of those who were employed full time and $18 \%$ of those employed part time, regardless of what year was taken as the reference period, found themselves out of work the following year. Of those who did manage to remain employed, $40 \%$ had to get by on the same or lower wages (Theodos \& Bednarzik, 2006). Over a third of low-wage employees work in the retail, food and beverage, or hotel industries, where there are few employment or training programs (Osterman, 2008), although one interesting experiment of union apprenticeship program has been documented (San Francisco Multiemployer Group and Hotel Employees and Restaurant Employees [HERE], Local 2; see Lynch, 2004, p. 301).

3 These results are part of a preprint (Legault, 2010). 
Women's relative position in terms of pay has generally been improving, when all educational levels are considered together. According to an analysis that aggregated three sources of U.S. national data, at least half of the improvement in women's relative position is due to the improvement in their educational level and qualifications and to their accumulated work experience (O'Neill \& Polachek, 1993). The remainder of the advancement, say the authors, is attributable to two factors. First, it can be attributed to the marginal returns on schooling and work experience (in other words, the benefits in terms of pay for each level of education completed - the "sheepskin effect" - or accumulated work experience), which, while positive for both sexes, is greater for women. Second, the decline in manufacturing jobs among men must also be considered. Returns on accumulated work experience have been improving because as women are staying longer in the labour market, they and their employers have been investing more in on-the-job training, and employers have been less reluctant to reflect these investments by increasing women's wages accordingly. These explanations amount to very good news for women who have access to training, but are of little comfort to women who do not (O'Neill \& Polachek, 1993).

It is all the more important to increase access to non traditionally female jobs for poor women moving from welfare to work under the new workfare regimes, because this offers an opportunity for women to support their families and move out of poverty (well illustrated by Bingham \& Gansler, 2002).

\section{On-the-Job Training is Not Well Developed in Women's Occupations Requiring Little Education}

Women who hold jobs requiring few skills but would like to improve their situation through on-the-job training face a further obstacle. According to a U.S. survey of managers (Black \& Lynch, 2001), in $53 \%$ of non-manufacturing companies and $46 \%$ of manufacturing firms, the skills required for relatively unspecialized production work or for front-line service work expanded in the 1990s as a result of increased computerization and reduced supervision, whether principally men's or women's jobs. A wide range of different jobs is referred to here. This gives employees greater responsibility for problem solving and decision making. While these jobs are still among those requiring the least qualifications, the level they do require has risen somewhat. Yet $38 \%$ of job candidates do not have sufficient command of basic reading, writing and arithmetic skills, and $31 \%$ of employers say they cannot find enough workers with the necessary qualifications for low-skilled jobs (Lynch, 2004, p. 294). A quarter of all workers also say they are not sufficiently prepared (Leuven \& Oosterbeek, 1999).

Given this situation, on-the-job training could be an attractive option, since it would give workers access to better-paid jobs through internal mobility. Surveys show that on-the-job training opportunities increase with the level of qualification already attained (qualified 
workers stand a better chance of being offered further training), with unionization and with the size of the organization ( $16 \%$ of small businesses offer training, compared with $80 \%$ of large companies) (Lynch, 2004, p. 294-5). An employer's interest in such training declines as a worker's mobility in the job market increases, since the employer runs the risk of losing its investment. But the least-qualified and poorest-paid employees are the most mobile, and what is more, any training they get may add to their mobility (Lynch, 2004, p. 295). The jobs held by the least-qualified women are the ones in which employers invest the least in on-thejob training: sales clerk, cashier, server, receptionist, office clerk, hairstylist, industrial sewing machine operator, visiting homemaker, teacher's assistant and school aide, babysitter, esthetician, etc. As a result, women have limited opportunities for on-the-job training (Consultation Group on Employment Equity for Women, 1995).

\section{Employment Equity Programs are Not Very Successful in These Sectors}

While some employment equity programs have led to significant progress in achieving a mixed-gender workforce in certain occupations, the Quebec government's incentive-based approach has produced feeble results in terms of desegregation (Agocs, 2002, Chicha, 2001, England \& Gad, 2002) especially among those with the least education. Analysts have come to the same conclusion regarding U.S. programs of the same type (Leonard, 1989, 1990).

The two most recent assessments of Quebec programs date from 1998 (Chicha, 2001; CDPDJQ, 1998), but we will have to make do with them, as the information supplied by companies under this program is not accessible to researchers.

Between December 1989 and 2010, 295 companies have been required to participate in the contractual obligation program (CDPDJQ, 2008), under which they must implement an equal access program before they may receive a contract or grant worth $\$ 100,000$ or more from the Government of Quebec.

Few companies have fulfilled their obligations and completed the process involved in the program, but 60 are in the implementation phase. This means they haven't finished carrying out their program and so haven't obtained any results. Only 14 companies have been sanctioned (preventing them from bidding for a contract or applying for a grant from the government until they have fulfilled the terms of their undertaking) and have therefore suffered the consequences (CDPDJQ, 2008, pp. 81-82). Same poor results, pointing towards lack of political will, poor funding, enforcement and surveillance, insufficient stringency in application, lack of sanctions have been observed at the Canadian level 
programs (Agocs, 2002; see table 8) and the US programs as well (LaTour, 2008; O'Farrell, 1999).

The number of women employed in the organizations subject to the contractual obligation rose $3.4 \%$ between 1989 and 1996, while total employment in them declined $4.9 \%$. But women made progress in particular in professional and technical positions and, though to a lesser degree, in managerial and supervisory positions. Blue-collar jobs represent the last frontier; in 1998, the CDPDJQ estimated that the number of women employed in blue collar occupations would have to rise by $13 \%$ in order to meet the objectives of the programs set up under the contractual obligations. The fact that men from cultural communities are making inroads in blue-collar employment indicates that the real problem here is women's access to predominantly male occupations, especially in the private sector.

On the Canadian federal level, the Employment Equity Act (EEA) applied to 1,121,770 public- and private-sector workers who came under federal jurisdiction and to 636 employers (with 100 or more employees) in 2008 (Human Resources and Skills Development Canada HRSDC, 2009). According to the annual reports on the application of the EEA, women's representation in the private sector went from $40.9 \%$ of the total workforce in 1987 to $42.7 \%$ in 2008 (HRSDC, 2009). This very small increase did not even meet the low EEA standard, as women's availability for the jobs offered in these companies was $48.1 \%$ of the labour force.

In 2007, the highest proportions of women were still found among administrative and senior clerical personnel $(75.5 \%)$, clerical personnel $(66 \%)$, and intermediate sales and service personnel (64.3\%). Women remain underrepresented in senior management $(21.9 \%)$ and among semiprofessionals and technicians (19.4\%) (HRSDC, 2009, Table 1.3).

Among manual workers in low-wage occupations requiring few qualifications (not requiring a recognized, exclusive skill - last column of Table 8), women's representation has been going up and down. Among semiskilled manual workers, women's representation has increased, while among skilled crafts and trades workers it has risen, though remaining extremely low (all these three groups involve occupations requiring a high school diploma or less). The skilled crafts and trades group is very significant in assessing the progress women are making in blue-collar employment, as recognized certification is required to practise these trades and ensures exclusivity. What is more, these occupations are the best-paid in relation to the level of education required and are the most often unionized.

In the workforce to which the EEA applies, the improvement in women's representation in blue-collar jobs has been small and unsteady among skilled crafts and trades workers and among other less or unskilled manual workers. 
Table 8

Percentage of women in three major blue-collar occupational groups in the federally regulated private sector

\begin{tabular}{llcc}
\hline Year & $\begin{array}{c}\text { Skilled crafts and trades } \\
\text { workers }\end{array}$ & $\begin{array}{c}\text { Semiskilled manual } \\
\text { workers }\end{array}$ & Other manual workers \\
\hline 1987 & 1.4 & 4.4 & 8.3 \\
1992 & 2.6 & 6 & 11.7 \\
1993 & 2.9 & 4.5 & 11.4 \\
1994 & 2.9 & 6.9 & 8.5 \\
1995 & 3.1 & 7.4 & 8.7 \\
1996 & 3.2 & 5.7 & 10.2 \\
1997 & 4.6 & 6.8 & 10.4 \\
1998 & 2.4 & 6.7 & 16.3 \\
1999 & 2.6 & 11.8 & 13.6 \\
$\mathbf{2 0 0 0}$ & 2.8 & 6.7 & 10.4 \\
$\mathbf{2 0 0 1}$ & 3 & 11.4 & 8.9 \\
$\mathbf{2 0 0 2}$ & 3.3 & 11.4 & 7.3 \\
$\mathbf{2 0 0 3}$ & 3.7 & 10.9 & 4.7 \\
$\mathbf{2 0 0 4}$ & 3 & 11.6 & 10.7 \\
$\mathbf{2 0 0 5}$ & 3.3 & 11.8 & 11.2 \\
$\mathbf{2 0 0 6}$ & 3.4 & 11.9 & \\
$\mathbf{2 0 0 7}$ & 3.6 & 12.6 & 0.3 \\
\hline & & & \\
\hline
\end{tabular}

Source: HRDC, 1988-2002; HRSDC, 2003-2008.

In short, in purely quantitative terms, progress has been rather slim in the blue-collar occupational groups.

Equity programs, in place in Canada for the past 25 years, have failed time and again in blue-collar sectors, although they are working well in white- and pink-collar sectors. There are many factors leading to such a situation. Since the mid-nineties, Canada, and its provincial governments as well, are retreating from policy response to systemic discrimination, under the influence of both the rise of neo-conservative ascendant and an important American backlash movement against affirmative action and their "reverse 
discrimination" effect of reducing men hiring and promoting; this last movement is embodied in three major ballot initiatives that have led to the banning of affirmative action following much publicised cases in education: California Civil Rights Initiative (Proposition 209), November 1996, followed by Washington State Civil Rights Initiative (Proposition 200), November 1998 et de Michigan Civil Rights Initiative (MCRI, Proposal 2, Michigan 06-2). These three propositions have eliminated Affirmative action altogether for women and minorities in state employment, education, and contracting. Similarly, the Civil Rights Act introduced in Congress in 1997 would end affirmative action for federal programs (LaTour, 2008; O'Farrell, 1999).

We must also note that the compliance review process is inadequately resourced and insufficiently stringent; significant sanctions simply do not exist for employers who fail to implement their requirements. Those same requirements are set very low, given that employers just have to hire minorities as much as the market does; there are no sanctions for failing to remove job barriers identified in the employment systems review, or for hiring members of a designated group into a job ghetto of poor jobs where women, handicapped people or immigrant workers are over-represented. An employer who fails to implement the requirements can lose the opportunity to bid on future federal contracts as a sanction but... this is never applied. There is no surprise, as the Human Rights Commission is underfunded and does not have the needed budget for conducting audits (Agocs, 2002).

Good blue collar jobs have always been the most resistant to women's integration; explanations for this rest heavily on case studies among which some constant trends may be rigorously analysed. There is, for instance, a steady decline in manufacturing, which may account for a defensive reaction from the blue collar workers; but labour force projections suggest that blue collar work will continue to be an important source of employment for women as well as men. Thus, for the foreseeable future, blue collar work continues to offer opportunities for women; whether they will be employed in skilled trades or in sweatshops is more of a concern.

Sex stereotyping in curricula, teachers' attitudes, and administrative practices also often deny girls the early preparation they need to enter vocational and academic programs that lead to high paying skilled jobs (Harlan \& Berheide, 1994; O'Farrell, 1999). Established human resources (HR) practices and hostility from managers and co-workers remain obstacles to women's entry and success in blue collar jobs (O'Farrell, 1999).

Furthermore, in the building and craft trades, some other obstacles are well known: a brotherhood culture excluding women, with men resenting the loss of a monopoly on high wage jobs and the loss of gender privilege at home, resenting the loss of masculine pride in doing a harsh, dangerous but skilled and useful job as well, resenting the pressure to drop 
their coarse or macho customs and language, fearing a loss of prestige and lower wages, the cost of harassment and health and safety complaints, and the constraint of maternity and children among women (Eisenberg, 1998; LaTour, 2008; Moccio, p. 77-98). In an enlightening class analysis of this situation among building trades workers, Paap (2006) offers a materialist interpretation of workers' and unions' labour market closure (to avoid competition over a very rewarding market given the low level of education required) and of the closed system of training and hiring, controlled by unions (for a dominated class has therefore gained the possibility to pass on a privilege to its heirs - though most often only to males...). Both are crown jewels of paramount importance for male workers in the field.

A further factor may involve the fact that shift work is common among both skilled and unskilled workers. This usually involves rotation between day and night shifts which may deter women from contemplating such a career.

But above all, we need to stress that this very fact that equity programs had more success in improving vertical mobility (women's access to management and professional jobs) than in improving horizontal mobility (women moving to men's jobs) is not a local matter, but a universal one (Charles \& Grusky, 2004, p. 3-8). In industrialized developed countries, there is a widespread combination of slow-paced desegregative change (horizontal desegregation) which can be compared with corresponding rates of change elsewhere in the gender stratification system (vertical segregation, hierarchical gaps) and the failure of egalitarian policies to reduce gender segregation in jobs, although we can observe good effects of these policies on women's access to higher-level jobs (vertical desegregation). According to Charles \& Grusky, though we can see cross-national variations in segregated and desegregated occupations, there are substantial commonalities in the underlying structure of segregation, based on quantitative analyses of standardised survey data. It has proven useful to distinguish between the vertical and horizontal forms of segregation, because the former is more effectively undermined by the rise of egalitarian institutional practices than the latter... as a result, there is a persistent hypersegregation of manual and nonmanual work in the lowest-level jobs (Charles \& Grusky, 2004, p. 27).A complete understanding of that phenomenon has not yet been achieved, because the authors put forward an essentialist explanation that fails to persuade the present author.

\section{WHAT NEEDS TO BE DONE?}

Pay equity legislation seems ineffective for women's jobs requiring the least education, as we can here see, after 15 years of implementation. It is not that we do not know better ways to proceed; for instance, the pay equity process can hardly redress inequities in organizations that are filled with female jobs, for instance primary schools, childcare centers, 
social service organizations, but also garment manufacturers, retail stores, big offices, personal service enterprises, private home care and health organizations. Obviously, the women employed in such female-dominated organizations are underpaid since similar jobs in organizations that employ men and women (e.g., municipalities) tend to be underpaid. For that reason, proxy comparison allows predominantly female organizations to compare with a public sector organization that employs similar female jobs (and male comparators) (for the notion of comparator, see the section above about Pay equity in Canada) such as a municipality or hospital. In Ontario, this radical approach overcame the lack of pay equity coverage for female jobs in those sectors of the economy most likely to require it. Still, proxy comparison was limited to the public sector because it was felt to be too intrusive to require private sector organizations to share wage information with their competitors (Weiner, 2002). Proxy comparison has not been considered in Quebec's Pay equity act. In light of the above, such a political compromise should be reconsidered.

Pay equity bargaining follows the same pattern, because blue- and white-collar workers are usually in separate bargaining units, and blue-collar unions do not want to be used as a comparator for clerical jobs. They feel this would violate the "fair comparison" principle. Interestingly, under Quebec's Pay equity legislation, a pay equity plan is prepared for the entire organization... unless a union makes a request that it be allowed to prepare a separate pay equity plan for the jobs it represents! There's an ongoing resistance from male unions to be used as comparators for female jobs (Forrest, 2007; Haiven, 2007), this can be easily understood - though not excused - as soon as you understand how wages are influenced by the gender of the workforce (the crowding effect, Sorensen, 1990).

How does this issue relate to responsible employment practices? Leck and Sanders (1996) found that the presence of formalized equity programs, those characterized by goals, timetables, plans, audits and a responsible manager, was related to increases in the representation of minorities in both management and nonmanagement jobs; the same was found to be true in universities (Stewart and Drakich, 1995). Another success factor is the implementation of actions designed to remove discriminatory barriers and systemic obstacles, among others an anti-harassment policy (Agocs, 2002), very important in maledominated blue collar environments where sexist harassment is a powerful deterrent and drives/keeps many women out of the field (Bingham \& Gansler, 2002; LaTour, 2008; Moccio, 2009). Such a level of requirements means nothing without surveillance, which in return requires funding. There is a cruel lack of funding in employment equity policy. In general, however, the Government of Quebec has opted for a voluntary approach with respect to private employers, and a proactive one with the public sector (Act respecting equal access to employment in public bodies, RSQ, ch. A-2.01). As a result, most corporations do not care for equity policy or else settle for some timid measures when subject to "contractual 
obligation", while the Human Rights Commission has no means to control. In fact, though organizations that do not comply may be sanctioned, only 14 out of 299 involved since 1989 have been so, and only six have completed their programme... (CDPDJQ, 2009, p. 83-4). What we clearly need is a proactive law, given the results obtained in the Canadian public sector where there is such legislation.

As a result, there is a general failure, since 1980, to adequately enforce the equal employment laws at the local workplace. Thus:

Supply explanations are inadequate on their own; obstacles stemming from the workplace figure heavily into the under-representation of women in skilled blue-collar jobs. (Padavic, 1997, p. 150).

Case studies, small surveys, and stories of individual blue collar women have consistently found that within workplaces there are often a small number of very hostile men, a small number of very supportive men who help women survive, and a large group of men in the middle who may be swayed in either direction (O'Farrell, 1999; Eisenberg, 1998). Apparently, we could lean upon this larger group, provided the right conditions are put forward:

Attitudes of the ambivalent group, however, are likely to be affected mainly by whether or not their own jobs are threatened, and the extent to which they associate women coming into the job with their work being deskilled, devalued, or eliminated altogether. We find less hostility towards women when men's jobs were not threatened by concerns such as lay-offs. (O'Farrell, 1999, p. 707)

For women with a high school diploma or less, blue-collar jobs, far better paid than what they are accustomed to, represent an attractive option, but one that it is hard for them to gain access to. That is why employment equity policies are a major issue, though we may wonder if any measure can succeed despite the industry's very reluctance, that experts can analyse thouroughly, but without being able to propose many adequate solutions :

Although Moccio does indeed attempt to describe the basis of male electricians' overwhelmingly negative reactions to the entrance of women in the trade, her solutions don't seem to address those issues specifically (Cook, 2010).

According to one recent publication (Rubery \& Grimshaw, 2003, pp. 103-4), these policies are even the major contemporary employment issue for women in Europe and North America. Internationally, women have been making significant progress in education, and as a result great strides in the professions and in managerial and white-collar occupations. But few countries have really solved the problem of poorly educated women gaining access to decent jobs. For men with the same level of schooling, the situation is very different; jobs in the skilled crafts and trades and in semiskilled manual work are much better paid than the predominantly female jobs held by women with the same education. To change this, not only do we need a far stronger commitment from the government, but also do we need far more ways to control and monitor the application of equity programs on the shop floor, and 
particularly to apply sanctions against harassing practices, to help women stay in their jobs and attract new women to the field.

The main flaws in implementing these programs are more than well-known as are the ways to enhance implementation. In summary, HR practices (the formal and informal procedures that employers use to recruit, train, and promote workers) can exclude women and minorities, due to a sexist bias, even when they appear neutral on the surface. These procedures are part and parcel of maintaining a segregated workforce and culture or, conversely, of getting rid of it. An effective employment equity policy should take control of the following in order to desegregate the workplace:

- moving away from individual complaints to class action suits or proactive affirmative action legislations, which have proven effective in case of discrimination or harassment (Bingham \& Gansler, 2002; LaTour, 2008);

- enforcing goals and schedules that are subject to sanctions, first and foremost in all big state-funded infrastructure-building initiatives; there is strong evidence that affirmative action policies, coupled with strong monitoring and the threat of financial sanctions for noncompliance, have had positive results for women and minorities (Legault, 2003; Leonard, 1989, 1990; Reskin, 1998);

- ensuring strong government support of equity policy, taking the same form as the World War II campaign to attract women into the industrial workforce: posters, ads in nationwide magazines, songs displayed to large public audiences; it is in no way "normal" that the post-Civil Rights Act campaign to get women into trades and technology does not benefit from the same support as WWII campaign did and was left only in the hands of feminist movement (LaTour, 2008);

- introducing court-ordered affirmative action programs when discrimination in hiring is demonstrated;

- for large national initiatives, focusing on sectors where there is job growth, where workers are likely to be more hospitable to women, who will have more opportunities and will meet less resistance: for example, among data processing equipment repairers, in the construction trades (including road construction) and among mechanics, installers and repairers, such as auto mechanics, transportation and material-moving machine and vehicle operators, and truck drivers (O'Farrell, 1999);

- targeting outreach and recruitment practices, so that women learn about job openings or requirements (Reskin, 1998); using more advertising, for instance, instead of informal referral; promoting internal mobility for women in mostly female jobs, with bridges connecting clerical jobs to skilled job ladders; using job fairs and popular magazines and associating with trades-women recruiters;

- targeting vocational training programs, so that more women enrol in mainly male programs; such a measure must be associated with severe enforcement of 
antidiscrimination rules during training; training instructors must be trained not to reinforce negative stereotypes about women's inability to do men's work; training material has to be elaborated to include women;

- eliminating unnecessary job requirements that most of all reflect the attributes of male incumbents rather than the requirements needed to perform the job and are based on bias (Chertos and Philips, 1989);

- eliminating tests that have been invalidated by the courts for lack of job-relatedness and for having a disparate impact on women, as well as on minority men (as when both are disproportionately screened out by body-size requirements);

- making a particular effort to avoid assigning women to work sites, departments, or shifts where there are no other women; their isolation is further exacerbated in a hostile work environment where the men do not talk to them or cooperate with them (Eisenberg, 1998; Legault, 2003);

- providing proper tools, protective clothing that fits and is ergonomically sound, as well as access to bathroom and changing facilities that are safe; when needed, providing sleeping accommodations that are safe and secure (Robbins, 1997);

- taking antiharassment measures, with consequences and sanctions for hostile work environments, including sabotage, assaults, pornography, unwelcome sexual remarks, touching or asking for sex, and so forth; providing on-the-job mentoring programs and sexual harassment prevention programs, training sessions that can help improve men's behavior, if not necessarily their attitudes and beliefs, and can help women learn how to deal effectively with offensive behavior when it does occur (Legault, 2003).

These interventions, however, all take strong leadership, time, effort and resources on the part of employers and unions. Few undertake efforts voluntarily despite the potential benefits, such as solving recruitment problems for employers and getting new members for unions. Affirmative action has, as we have above seen, been under attack, first in the US, then in Canada by ricochet. The outcome of the ongoing debate about affirmative action is likely to have a considerable effect on women's inroads into blue-collar jobs.

\section{CONCLUSION}

Despite widespread popular belief, the labour market is still deeply segregated by gender, and the material consequences of this segregation are most serious in occupations that require less education, where women pay dearly for the sexual division of labour. In contrast to occupations requiring higher qualifications, there is a very significant pay gap in men's favour in those requiring few qualifications, in which many jobs are either predominantly male or predominantly female. This pay gap to the disadvantage of women is seen very 
widely in occupations requiring a high school diploma or less. It has been narrowing only very slightly, whereas the gaps between men and women in jobs requiring a higher level of education have been shrinking considerably. The pay gap in occupations requiring few qualifications affects close to 500,000 of the 1.8 million women in the Quebec labour force, in other words, between a quarter and a third. The question of equitable access to work is all too often regarded as a problem that has already been solved, but that is far from being the case. Moreover, the market rarely works in ways that help poor workers to improve their lot; and employers rarely invest in on-the-job training in the occupational groups in which poorly educated women are concentrated, although the situation is very different for men with the same level of education.

Will not there be a heavy price to pay for losing interest in this issue now, when the mosteducated and most-qualified women have made great gains, often thanks to these same affirmative action measures, for instance in the public services?

It looks as though we have given up too early on employment equity programs, because in the least-skilled jobs, pay inequity is still deeply rooted in employment segregation. 


\section{REFERENCES}

Agocs, Carol (2002) "Canada's Employment Equity Legislation and Policy, 1987-2000. The Gap between Policy and Practice", International Journal of Manpower, 23(3), 256-276

Alksnis, Christine, Serge Desmarais \& James Curtis (2008) "Workforce Segregation and the Gender Wage Gap: Is "Women's" Work Valued as Highly as "Men's"?", Journal of Applied Social Psychology, 38(6), pp. 1416-1441

Armstrong, P. and M. Cornish (1997) "Restructuring Pay Equity for a Restricted Work Force: Canadian Perspectives," Gender, Work and Organization, 4(2):67-86

Baker, M. and N.M. Fortin (1999) "Women's Wages in Women's Work: A U.S./Canada Comparison of the Roles of Unions and "Public Goods" Sector Jobs," AEA Papers and Proceedings, 89 (2):198-203

Beeman, Jennifer (2004) "Pay equity in Quebec: A right unknown to the women workers who need it most", Canadian Women Studies, 23 (3-4): 96-104

Bergmann, Barbara R., 1971, "The effect on white incomes of discrimination in employment", Journal of Political Economy, 79, pp. 294-313

Bergmann, Barbara R. 1974. "Occupational Segregation, Wages and Profits When Employers Discriminate by Race and Sex." Eastern Economic Journal 1:103-10

Bingham, Clara \& Laura Leedy Gansler (2002) Class Action. The Story of Lois Jenson and the Landmark Case that Changed Sexual Harassment Law, New York, Doubleday

Black, Sandra E. \& Lisa M. Lynch (2001) "How to compete: The impact of workplace practices and information technology on productivity", Review of Economics and Statistics, 83(3): 434-45

Blau, Francine, A. Ferber \& A. Winkler (2002) The Economics of Women, Men and Work, Upper Saddle River, Prentice-Hall

Blau, Francine \& Lawrence Kahn (2000) "Gender differences in pay", Journal of Economic Perspectives, 14, 75-99

Charles, Maria \& David B. Grusky, 2004, Occupational Ghettos. The Worldwide Segregation of Women and Men, Stanford, $\mathrm{Ca}$, Stanford University Press

Chertos, C. H., \& Phillips, S. C. (1989) "Physical training as a strategy for integrating municipal uniformed services". In S.L. Harlan \& R.J. Steinberg (Eds.), Job Training for Women Philadelphia: Temple University Press, 290-315

Chicha, Marie-Thérèse (2001) "Les politiques d'égalité professionnelle et salariale au Québec; l'ambivalence du rôle de l'État québécois », Recherches féministes, 14(1), 6382

Chicha, Marie-Thérèse (2006) A comparative analysis of promoting pay equity: Models and impacts, Geneva, International Labour office 
http://im.metropolis.net/research-policy/research_content/doc/WP49_chicha.pdf

Cloutier, Luc (2008) La qualité de l'emploi au Québec, développements conceptuels et création d'une typologie. État actuel de la réflexion, Quebec city, Institut de la statistique du Québec

Commission des droits de la personne et des droits de la jeunesse du Québec (CDPDJQ) (2003a) Guide d'élaboration d'un programme d'accès à l'égalité en emploi, Direction des programmes d'accès à l'égalité, CDPDJQ, gouvernement du Québec, Québec

Commission des droits de la personne et des droits de la jeunesse du Québec (CDPDJQ) (2003b) Guide pour l'analyse du système d'emploi, Direction des programmes d'accès à l'égalité, CDPDJQ, gouvernement du Québec, Québec

Commission des droits de la personne et des droits de la jeunesse du Québec (CDPDJQ) (1998) Les programmes d'accès à l'égalité au Québec. Bilan et perspectives. Maintenir les acquis, élargir le champ d'action, Résumé, Montréal, gouvernement du Québec

http://www.cdpdj.qc.ca/fr/publications/liste.asp? Sujet=39\&noeud1 $=1$ \&noeud2 $=6 \& c l e=0$

Commission des droits de la personne et des droits de la jeunesse du Québec (CDPDJQ)

(2008) Liste des entreprises soumises au programme d'obligation contractuelle, in page : Programmes en vertu de la charte, [on line] retrieved April 162008 http://www.cdpdj.qc.ca/fr/programme-acces-egalite/programmescharte. asp?noeud1 $=1 \&$ noeud $2=13 \&$ cle $=45$

Commission des droits de la personne et des droits de la jeunesse du Québec (CDPDJQ) (2009) Rapport d'activités et de gestion, in page : Programmes en vertu de la charte, [on line] retrieved January 2009 http://www.cdpdj.qc.ca/fr/publications/liste.asp?Sujet=11\&noeud1 $=1$ \&noeud2=6\&cle=0

Consultation Group on Employment Equity for Women (1995) Looking to the future: Challenging the cultural and attitudinal barriers to women in the public service. Treasury Board of Canada Secretariat, Ottawa

http://www.collectionscanada.gc.ca/eppp-archive/100/201/301/tbs-sct/tb manualef/Pubs_pol/hrpubs/TB_852/LF5-27E.html

Cook, Kristen (2010) Review of "Live Wire: Women and Brotherhood in the Electrical Industry", By Francine A. Moccio Temple University Press, published in Feminist Review, Saturday, January 30

http://feministreview.blogspot.com/2010/01/live-wire-women-and-brotherhood-in.html

Drolet, Marie (2001) The Persistent Gap: New Evidence on the Canadian Gender Wage Gap, Ottawa, Statistics Canada, Business and Labour Market Analysis Division

Eisenberg, Susan (1998) We'll Call You If We Need You. Experiences of women working Construction, Ithaca, Cornell University Press

England, Kim \& Gunter Gad (2002) "Social Policy at Work? Equality and Equity in Women's Paid Employment in Canada", GeoJournal, 56: 281-294

Forrest, Ann (2007) "Bargaining against the past: Fair Pay, Union Practice, and the Gender 
Pay Gap", in Gerald Hunt and David Rayside, Equity, Diversity, and Canadian Labour, Toronto, University of Toronto Press, p. 49-74

Gunderson Morley (1998) Women and the Canadian Labour Market. Transitions towards the future. Statistics Canada and ITP Nelson, Ottawa and Toronto

Gunderson, Morley (2006) "Viewpoint: Male-female wage differentials: how can that be?", Canadian Journal of Economics / Revue canadienne d'économique, 39(1), 1-21

Gunderson, Morley \& Leon Muszynski (1990) Women and Labour Market Poverty, Ottawa, Canadian Advisory Council on the Status of Women

Haiven, Judy (2007) "Union Response to Pay Equity: A cautionary Tale", in Gerald Hunt and

David Rayside, Equity, Diversity, and Canadian Labour, Toronto, University of Toronto Press, p. $75-100$

Harlan, S. L., \& Berheide, C. W. (1994) Barriers to workplace advancement experienced by women in low-paying occupations. Washington, DC: U.S. Department of Labor, Glass Ceiling Commission

Hölzer, Harry J. (2004) Encouraging job advancement among low-wage workers: A new approach, Brookings Institution Policy Brief No. 30, Washington, The Brookings Institution

Human Resources Development Canada (HRDC) (1988-2002) Employment Equity Act Annual Report, government of Canada

Human Resources and Skills Development Canada (HRSDC) (2003-2009) Employment Equity Act Annual Report, government of Canada

LaTour, Jane (2008) Sisters in the Brotherhoods, Working Women Organizing for Equality in New York City, New York, Palgrave

Leck J., S. St-Onge \& I. Lalancette. (1995) "Wage gap changes among organizations subject to the Employment Equity Act", Canadian Public Policy, 21(4): 203-320

Leck, J. \& Saunders, D. (1996) "Hiring women: the effects of Canada's Employment Equity Act", Canadian Public Policy, 18(2): 203-20

Legault, Marie-Josée (2002) Équité en emploi - Équité salariale, Université du Québec Télé-université, Québec

Legault, Marie-Josée (2003) Workers' resistance to women in traditionally male sectors of employment and the role of unions. Labor relations issues arising out of three case studies, Notes de recherche, Direction de la recherche, Télé-universitéLegault, MarieJosée \& Marik Danvoye (2007) Construire avec elles. Les mesures d'accès et de maintien des femmes dans l'industrie de la construction. Analyse de données statistiques secondaires, Rapport d'étape déposé au comité d'encadrement du projet Construire avec elles (FRONT-CSN-Construction-Services aux collectivités de I'UQAM-TéluqUQAM), may, 93 pages

Legault, Marie-Josée (2010) "Is there such thing as employment and pay equity for the less educated in Québec?", Preprint in open access: 
http://bit.ly/1NVAFo

Leonard, Jonathan (1989) "Women and Affirmative Action", Journal of Economic Perspectives, 3(1), 61-75

Leonard, Jonathan (1990) "The Impact of Affirmative action Regulation and Equal Employment Law on Black Employment”, Journal of Economic Perspectives, 4(4), p. 4763

Leuven, E., and Hessel Oosterbeek (1999) "Demand and supply of work-related training: Evidence from four countries", Research in Labor Economics, 18: 303-30

Lynch, Lisa M. (2004) "Development Intermediaries and the Training of Low-Wage Workers", in Richard B. Freeman, Joni Hersch \& Lawrence Mishel (ed), Emerging labor market Institutions for the Twenty-first Century, National Bureau of Economic Research, 293 314; available on line : http://www.nber.org/books/free04-1

Moccio, Francine (2009) Live Wire, Women and Brotherhood in the Electrical Industry Philadelphia, Temple University Press

O'Farrell, Brigid (1999) "Women in Blue Collar and Related Occupations at the End of the Millennium," Quarterly Review of Economics and Finance 39: 699-722

O'Neill, June \& Solomon Polachek (1993) "Why the Gender Gap in Wages Narrowed in the 1980s", Journal of Labor Economics, 11(1), 205-228

Osterman, Paul (2008) "Améliorer la qualité du travail peu rémunéré; l'expérience des États-

Unis", Revue international du travail, 147(2-3), 123-144; for a close English version, Osterman, Paul (2008) Improving job quality. Policies Aimed At the Demand Side of the Low Wage Labor Market, Boston, MIT Sloan School

http://web.mit.edu/osterman/www/revised\%20ostermanupjohn.pdf

Paap, Kris (2006) Working Construction. Why White Working-Class Men Put Themselves and the Labor Movement - in Harm's Way, Ithaca, Cornell University Press, 2006

Padavic, I. (1997) "Women in blue-collar occupations". In P. J. Dubeck \& K. Borman (Eds.), Women and Work: A Reader, New Brunswick, NJ: Rutgers University Press, 147-152

Reskin, B. F. (1998). The Realities of Affirmative Action in Employment, Washington, DC, American Sociological Association

Robbins, L. (1997) "Build a safe work site for every size, shape and sex". Safety Health, April, 52-55

Rubery, Jill \& Damien Grimshaw (2003) The Organization of Employment. An International Perspective, Houndmills, Palgrave MacMillan

Sorensen, Eileen (1990) "The Crowding Hypothesis and Comparable Worth", The Journal of Human Resources, 25(1), 55-89

Stewart, P. \& Drakich, J. (1995) "Factors related to organizational change and equity for Women faculty in Ontario universities", Canadian Public Policy, 21(4): 429-48

Theodos, Brett \& Bednarzik, Robert (2006) "Earnings mobility and low-wage workers in the United States", Monthly Labor Review, 129(6), 34-47 
Weiner, Nan (2002) Effective Redress of Pay Inequities, Canadian Public Policy - Analyse de politiques, vol. 28, no special 1, p. S-101 - S 115 